\title{
A BRUTA ANIMALIA LATIN FORDÍTÁSAI: GIOVANNI ÉS RAFFAELE REGIO*
}

\begin{abstract}
Plutarchos Bruta animalia ratione uti című dialógusának humanista latin fordításai közül a legismertebb Giovanni Regio nevéhez füződik. Az 1488-ban készült fordítást, amelyet a Padovai Egyetemi Könyvtár Ms. 958 jelzetű papírkódexe őriz, Raffaele Regio, a fordító testvérbátyja átdolgozta, és 1508-ban Velencében posztumusz kiadta. A kézirati és a nyomtatott szöveg egybevetését a kutatás még nem végezte el. A beható filológiai elemzéssel az a célunk, hogy megállapítsuk az eredeti fordításba való beavatkozás mértékét és természetét, majd ennek révén közelebbi bepillantást nyerjünk a fordító eljárási módszerébe és technikáiba. Ezzel alkalmunk nyílik a fordítás szövegének további kapcsolatait is megvizsgálni a dialógus másik két latin fordításával, amelyeket Antonio Cassarino és Lampugnino Birago készített néhány évtizeddel korábban.

Kulcsszavak: Plutarchos, Bruta animalia ratione uti, Giovanni és Raffaele Regio, humanista latin fordítások
\end{abstract}

Plutarchos Bruta animalia ratione uti címü dialógusát (a továbbiakban csak Bruta animalia) az utókor méltán tartotta a Moralia egyik legérdekesebb és legszórakoztatóbb darabjának. Szakítva a hagyományos plutarchosi dialógus formájával ez a párbeszéd mitológiai alakokat léptet fel a részt vevő felek szerepében: Kirkét és Odysseust a keretelbeszélésben (1, 985d-986b), illetve Odysseust és egy disznót, Gryllost a párbeszéd fő részében (2-10, 986c-992e).

A dialógus tartalma röviden a következö: ${ }^{1}$ Odysseus a homérosi eposz szelleméhez hűen éppen tovább készül indulni Kirkétől, ám előbb megkérdezi, van-e esetleg más görög is, akit bájitalával az istennő vadállattá változtatott. Kirké igennel felel, mire Odysseus a becsvágytól fütve kéri, hadd vigye ezeket is haza magával, miután emberi formájukat visszanyerték. Kirké azonban meglepő módon azt válaszolja, nem biztos, hogy ők maguk is akarják, ezért kérdezze meg őket, vagy ha vonakodnának, győzze meg őket érvekkel, hogy jól felfogott érdekük visszaváltozni emberré. Egy disznót, Gryllost, azaz 'Röfit' jelöli ki arra a feladatra, hogy vitába szálljon Odysseusszal. Gryllos igen csavaros érvekkel bebizonyítja a hősnek, hogy az állati életforma minden tekintetben fölötte áll az emberinek. Az emberi bátorságról ( $\alpha \nu \delta \rho \varepsilon i \alpha)$, Odysseus fő erényéről bebizonyosodik, hogy merő csel és ravaszság, sőt valójában számító gyávaság. A mértékletességben ( $\sigma \omega \varphi \rho \circ \sigma u ́ v \eta)$ az állatok számtalan példával képesek bebizonyítani a felsőbb-

* A jelen tanulmány a K 112283 számú OTKA-projekt keretében készült.

1 A modern szövegkiadásokhoz lásd C. Hubert: Plutarchi Moralia. Vol. 6. Fasc. 1. Leipzig 1954. 76 skk.; W. C. Helmbold: Plutarch's Moralia. XII: 920 A-999 B. Cambridge 1957. 487 skk.; G. Indelli: Plutarco, Le bestie sono esseri razionali. Napoli 1995. 
rendűségüket, míg az emberek a hiú vélekedések rabjaiként hajszolják az élvezeteket. Végül az okosság ( $\varphi \rho o ́ v \eta \sigma ı \varsigma)$ terén az állatok sokkal magasabb képességről tanúskodnak, mint az emberi ész vagy értelem ( $\lambda$ ó $\left.\varsigma_{0}\right)$, hiszen a természet lehetővé teszi számukra, hogy tanulás és nevelés nélkül elsajátítsák a kinek-kinek szükséges mesterségeket. Odysseus az érvek hatására kénytelen fokozatosan meghátrálni és belátni, hogy jobb, ha Gryllost és társait meghagyja az állati létformában, és letesz becsvágyó tervéről.

$\mathrm{Ez}$ a kis darab érthető módon rögtön megragadta az emberi fantáziát, amint a humanizmus felszínre hozta, és görög nyelven, majd pedig latin fordításban elérhetővé tette a müvelt olvasóközönség számára Plutarchos erkölcsfilozófiai írásait. ${ }^{2}$ A Bruta animalia esetében kisebb utóéletről beszélhetünk, amely a XVI. század első felében csúcsosodott ki. Bár Rotterdami Erasmus még csak utalást tesz a müre mint az általa írott Stultitiae Laus (1511) egyik ókori előzményére, párhuzamba állítva a Balgaságot Gryllos oktalan bölcsességével, ${ }^{3}$ néhány évvel később már Niccolò Machiavelli L'asino című költeményében (1517) nyíltan kihasználja a témában rejlő lehetőségeket, amikor a plutarchosi dialógus mintájára alkotja meg költeményének zárófejezetét. ${ }^{4}$ Éles társadalombírálat érződik ki Girolamo Rorario Quod animalia bruta saepe ratione utantur melius homine címü művéből is (1544), amely egy aktuálpolitikai incidensből kiindulva még tovább tágítja a plutarchosi dialógus kereteit azáltal, hogy jelenbeli példákkal gazdagítja az állatok értelmessége és erényessége mellett szóló bizonyítékok sorát. ${ }^{5}$ Végül már filozófiai dimenziót ölt Giovanbattista Gelli $\mathrm{La}$ Circe című nagyszabású dialógusa (1549), amelyben az eredeti szándék is visszájára fordul, hiszen az állatok által felsorolt érvek száma és súlya ellenére Odysseus kerül ki győztesen a vitából, sikerrel járva abban, hogy meggyőzze az emberré való visszaváltozásról az egyetlen filozófushajlamú állatot, az elefántot. ${ }^{6}$

Mindezeknek az irodalmi átdolgozásoknak a forrásául nagy valószínűséggel a Bruta animalia egyetlen addig nyomtatásban megjelent latin fordítása szolgált. Ez a fordítás Velencében jött ki az 1508-as évben, és Giovanni Regio nevéhez füződik, akinek

2 A Moralia darabjainak a latin humanista műveltségben való felfedezéséhez vö. C. Bevegni: Appunti sulle traduzioni latine dei Moralia di Plutarco nel Quattrocento. StudUmanistPiceni 14 (1994) 71 skk.; F. Stok: Le traduzioni latine dei Moralia di Plutarco. Fontes 1-2 (1998) 117 skk.; F. Becchi: Le traduzioni latine dei Moralia di Plutarco tra XIII e XVI secolo. In: Plutarco nelle traduzioni latine di età umanistica. Ed. $P$. V. Cacciatore. Napoli 2009.

3 Moriae encomium, id est, stulticiae laus, Erasmi Roterodami declamatio. Paris, Gilles de Gourmont et Jean Petit, [MDXI].

4 L'asino d'oro di Nicolo Machiavelli, con alcuni altri cap. \& novelle del medesimo, nuovamente messi in luce, \& non piu stampati. In Fiorenza, appresso Bernardo Giunti, MDXLIX.

5 Biblioteca comunale degli Intronati, Siena Ms. H IX 6; Hieronymi Rorarii Exlegati Pontificii, Quod Animalia bruta ratione utantur melius Homine. Parisiis, apud Sebastianum Cramoisy, MDCXLVIII. Cum privilegio Regis.

6 La Circe di Giovanbatista Gelli Accademico Fiorentino. In Firenze con privilegio MDXLIX, appresso Lorenzo Torrentino. 
a fordítását posztumusz adta ki a saját kötetében Raffaele Regio, a fordító testvérbátyja. ${ }^{7}$ A kötet újrakiadást is megért. ${ }^{8}$ A század második felében azután a Regio-féle fordítást mintegy végleges rangra emelte Stephanus (Henri Estienne), aki az 1572-ben kiadott teljes görög Plutarchos-corpus fordításai közé választotta, néhány szükséges kiigazítást elvégezve a szövegen. ${ }^{9}$ Ha tehát nem számítjuk a Bruta animalia csupán kéziratokban fennmaradt másik két fordítását, amelyek közül az egyik a szicíliai Antonio Cassarino (1440-1445 körül), ${ }^{10}$ a másik a milánói Lampugnino Birago (1465-1470 körül) keze műve, ${ }^{11}$ akkor kizárólag a Regio-féle fordítás tarthatott számot közismertségre.

Érdekes azonban, hogy a Regio-féle fordítás kézirati formában is megőrződött. A Padovai Egyetemi Könyvtár tulajdonában lévő Ms. 958 jelzetű papírkódex 25+1 folióján egységes kézírással szerepel a kis mű ajánlással együtt Bruta ratione utantur címen. Az ajánlás Niccolò Francónak, Treviso püspökének van címezve, 1488. március 31-i padovai keltezéssel. Mind a két-két aranyozott iniciálé, amely az ajánlás és a fordítás elejét díszíti, mind pedig a fordítás kezdőlapján a püspök címerének jól kidolgozott, színes illusztrációja azt sejteti, hogy autográffal van dolgunk. ${ }^{12}$

Minthogy az ajánlás és a fordítás is Raffaele Regio kötetének részeként nyomtatásban is megjelent, nem volna különösebb jelentősége a kéziratnak, ha már a felszínes öszszevetésből is nem látszana, hogy a kézirat szövege alapos revízión esett át, feltehetően a szöveget közrebocsátó testvérbáty részéről. Ezek az eltérések kellően jelentősek ahhoz, hogy a jelen tanulmányban vizsgálat tárgyává tegyük őket. Különösen indokolja ezt az a tény, hogy nemigen szoktak tudomást venni erről a lényeges különbségről, valószínüleg

7 Plutarchi Regum \& Imperatorum Apophthegmata Raphaele Regio interprete. Plutarchi Laconica apophthegmata Raphaele Regio interprete. Plutarchi Dialogus, in quo animalia bruta ratione uti monstrantur, Ioanne Regio interprete. Impressum Venetiis opere et impensa Georgii de Rusconibus, MDVIII, die 2 octobris, $\left[76^{\mathrm{a}}-83^{\mathrm{a}}\right]$.

8 Plutarchi Chaeronei opuscula quaedam longe utilissima, Raphaele ac Ioanne Regio, Nicolao Saguntino, \& Guarino Veronen interpretibus. Moguntiae apud Ioannem Schoeffer, mense martio, MDXXII, 179-197.

9 Plutarchi Chaeronensis opuscula varia, quae magna ex parte sunt philosophica. Vulgo autem Moralia opuscula nimis angusta appellatione vocantur. Ex diversorum interpretationibus, quarum quaedam sunt Henrici Stephani, non antea editae. Anno MDLXXII, excudebat Henr. Stephanus. Cum privilegio Caes. Maiestatis, et Christianiss. Galliarum Regis, III, 339-351.

10 Vö. G. Resta: Antonio Cassarino e le sue traduzioni da Plutarco e Platone. IMU 2 (1959) 233 sk.; Bevegni: i. m. (2. jegyz.) 73, 76 és 79 sk.; Stok: i. m. (2. jegyz.) 123; Becchi: i. m. (2. jegyz.) 25 sk.; G. Indelli:

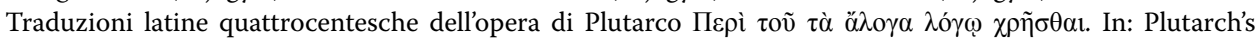
Writings: Transmission, Translation, Reception, Commentary. Eds. G. Pace - P. V. Cacciatore. Napoli 2013. 228 skk.

11 Vö. Bevegni: i. m. (2. jegyz.) 76 és 79 sk.; Stok: i. m. (2. jegyz.) 125; Becchi: i. m. (2. jegyz.) 30 sk.; Indelli: i. m. (10. jegyz.) $234 \mathrm{sk.}$

12 Az alfabetikus katalóguscédula bejegyzése szerint: [Ms. forse autogr.] 
azért, mert a kézirattal való alapos összevetés elmaradt. ${ }^{13}$ Márpedig értékes adalékok nyerhetők az eredeti fordító tudásszintjéről, fordítástechnikájáról, nyelvi készségéről, ha a javított szöveggel való összevetést elvégezzük. Ezenfelül vállalkozni szeretnénk arra is, hogy a kézirat szövegének esetleges mélyebb kapcsolatait is felfedjük a korábbi fordítások szövegével. Az így elénk táruló összefüggésrendszerben a görög szöveg humanista fordítása kevésbé fog egyéni érdemen alapuló teljesítménynek tűnni, mint inkább a korábbi eredményeket felhasználó törekvésnek egy jobb eredmény elérése érdekében.

Giovanni Regio életéről nem sokkal többet tudunk, mint amennyit bátyja elmond róla a fordítását közreadó kötetben. Ugyanebben a kötetben maga Raffaele is képviselteti magát két Plutarchos-fordítással (Regum et imperatorum apophthegmata, Laconica apophthegmata), amelyeket a megelőző években készített, ezért nyilván magától értetődött, hogy hozzácsapja ezekhez a Bruta animalia fordítását is, öccse emlékének tisztelegve. Így ír a megjelentetés körülményeiről: ${ }^{14}$

Nam una cum illis lepidissimum quoque Plutarchi ipsius dialogum, quem Ioannes Regius, mihi frater carissimus utriusque linguae cum primis doctus, paucis ante annis, quam in flore aetatis suae (nondum enim duodetriginta annos excesserat) dira peste in Romana aula raperetur, latinitate donavit, curavi describendum, simul ut fratris optimi, quem ipse institueram, qui me veluti patrem semper coluerat, memoria diuturnior efficeretur, simul quod dialogus ipse et lectu pulcherrimus, et cognitu dignissimus esse videtur.

Mert ezekkel [ti. a két Plutarchos-fordítással] együtt ugyanannak a Plutarchosnak egy igen szellemes dialógusát is kinyomattam, amelyet Giovanni Regio, az én legdrágább fiútestvérem, aki mindkét nyelvben különösen tanult volt, ültetett át latinra nem sok évvel azelőtt, hogy élete virágjában (hiszen még nem lépte túl a huszonnyolc évet) a szörnyü pestis által elragadtatott a római udvarban, mind azért, hogy az én legjobb fiútestvéremnek, akit magam tanítottam, és aki engem mindig úgy tisztelt, mint az apját, hosszan tartó emlék állíttassék, mind pedig azért, mert maga a dialógus olvasásra is a legszebb és megismerésre is a legérdemesebb. ${ }^{15}$

Minthogy az ajánlás időpontja az 1488-as évre esik, ehhez kell négy-öt évet hozzáadnunk, hogy megkapjuk Giovanni halálának és születésének a hozzávetőleges idejét. Az ifjú halála ezek alapján talán 1492-re esett, a születése pedig 1464-re. Raffaele kézirati feljegyzéseiből, illetve levelezésekből tudjuk, hogy az 1491-es év elején Giovanni

13 Lásd például még a legutóbbi időkben is $F$. Becchi: Problèmes textuels et choix d'interprétation dans les textes de psychologie animale de Plutarque. In: Plutarque. Éditions, Traductions, Paratextes. Eds. F. Frazier - O. Guerrier. Sao Paolo 2016. 156, n. 6. A különbségre viszont felhívta már a figyelmet Indelli: i. m. (10. jegyz.) 236.

14 Itt és a továbbiakban egységes latin átírást használok a szövegek közlésében a jobb érthetőség kedvéért.

15 Plutarchi Regum \& Imperatorum Apophthegmata Raphaele Regio interprete..., [3 $3^{\text {b }}$. 
még egyházi kiváltságban részesült Niccolò Francótól, a trevisói püspöktől, akinek a fordítását ajánlotta. ${ }^{16}$ Sőt valószínűleg ugyanebben az évben közbenjárt bátyja érdekében, hogy magasabb befolyás révén tanári álláshoz jusson Milánóban, miután a Padovai Egyetemen 1488-ban Giovanni Calfurnio sikerrel rántotta ki alóla a retorikatanári széket. ${ }^{17}$ Giovanni halála tehát 1492 körül következhetett be. Raffaele Regio életéről bővebb ismereteink vannak. Tudni lehet, hogy 1438 körül születhetett, magas kort ért meg, és főleg latin szerzőkkel (Cicero, Quintilianus) kapcsolatos munkássága miatt nagy megbecsülésnek örvendett. ${ }^{18} 1482-1486$ között görög és latin nyelvet oktatott a Padovai Egyetemen. A nála mintegy negyed évszázaddal fiatalabb öccsét talán éppen ezekben az években tanította, ahogy maga is említi. Ezután Giovanni feltehetően Niccolò Franco püspök szolgálatába állt titkárként, ennek köszönhette későbbi előmenetelét és talán a római udvarban való megfordulását is, ahol a halál érte. ${ }^{19}$

Érdemes közölni teljes terjedelmében a Bruta animalia fordításához tartozó ajánlást, különösen azért, mert Raffaele a nyomtatott változatban ennek a szövegében is jelentős változtatásokat hajtott végre. Az ajánlás az eredeti kéziraton így hangzik (a megelőző rubrica szövegével együtt):

Ad Reverendissimum in Christo patrem ac Dominum Dignitatem Nicolaum Francum episcopum Tarvisinum legatum apostolicum dignissimum Ioannis Regii epistola:

Plutarchi Chaeronensis philosophi in primis eruditi opusculum, in quo probare conatur, bruta quoque animalia non minus, quam homines, ratione uti, nuper exercitationis gratia e Greco in Latinum sermonem transtuli. Id tametsi minus fortasse dignum Reverendissima Dignitate Tua videbitur, idcirco tantum nomini tuo inscripsi, ut facile perciperet singularis Humanitas Tua me ei omnia mea propter assiduam in me liberalitatem semel dedicasse. Huc accedit, quod speravi te non minimum voluptatis ex huius libelli lectione percepturum. Nam neque vulgaris est quaestio, et hic lepide adeo tractatur, ut non minus ad delectationem, quam ad cognitionem composita videatur.

$[\ldots]^{20}$

16 C. Malta: Il commento a Persio dell'umanista Raffaele Regio. Messina 1997. 136 sk.

17 Malta: i. m. (16. jegyz.) 127 sk.

18 Az életrajzi adatokhoz lásd F. Pignatti: Regio, Raffaele. DBI 2016 http://www.treccani.it/enciclopedia/ raffaele-regio_(Dizionario-Biografico).

19 Nem lehet azonos a mi fiatal fordítónkkal az a velencei születésű Giovanni Regio, akiről Pierio Valeriano elmondja (De litteratorum infelicitate 23), hogy görög és latin nyelvben igen járatos volt, és miután VI. Sándor pápa idején megmérgezték Viterbóban, számos Plutarchos-művet hagyott hátra. Ez a személy ugyanis vélhetően a vatikáni könyvtáros és Plutarchos-fordító, Giovanni Lorenzi volt. Vö. téves azonosítással Indelli: i. m. (10. jegyz.) 235.

20 Itt a dialógus tartalmának rövid ismertetése következik. 
Sed Reverendissima Dignitas Tua si quando per negotia publica haec legere vacabit, facile diiudicabit non sine causa eam quaestionem a praestantissimo philosopho fuisse tractatam.

Bene valeat Reverendissima Dignitas Tua, cui me plurimum etiam atque etiam commendo.

\section{Patavii pridie Kalendas Apriles MCCCCLXXXVIII. ${ }^{21}$}

A legtiszteletreméltóbb keresztény atyának, Öméltósága Niccolò Franco úrnak, Treviso püspökének, a legméltóságteljesebb pápai legátusnak Giovanni Regio levele:

A chairóneiai Plutarchosnak, a különösen nagy műveltségű filozófusnak a müvét, amelyben megkísérli bebizonyítani, hogy az oktalan állatok is nem kevésbé, mint az emberek, rendelkeznek értelemmel, a minap gyakorlás kedvéért fordítottam le görögből latin nyelvre. Bár ez a mü talán kevésbé fog méltónak tűnni a Legtiszteletreméltóbb Méltóságodhoz, csak azért címeztem a te nevedre, hogy a te kivételes Emberséged könnyen megértse, hogy én egyszerre mindenemet felajánlom neki a te irántam való meg nem szűnő nagylelkűségedért. Ehhez járul még, hogy reméltem, nem csekély élvezetet fogsz nyerni ennek a könyvecskének az olvasásából. Mert a kérdés sem mindennapi, és annyira szellemesen van itt tárgyalva, hogy úgy tűnik, nem kevésbé a gyönyörködtetés, mint a megismerés céljára íródott.

[...]

Ám ha a Legtiszteletreméltóbb Méltóságodnak valamikor a közügyek intézése mellett lesz szabad ideje ezeket elolvasni, akkor könnyen meg fogja ítélni, hogy ezt a kérdést nem ok nélkül tárgyalta a legkiválóbb filozófus.

Jó egészséget kívánok a Legtiszteletreméltóbb Méltóságodnak, akinek újra meg újra csak ajánlom magamat.

Padovában, 1488. március 31-én.

Meglepő módon ez a dátum nem egyezik meg pontosan azzal, amit Raffaele a nyomtatott változatban jelez. Ott 1488. március 6-a szerepel (Patavii pridie nonas Martias MCCCCLXXXVIII). Erre talán az adhat magyarázatot, hogy a bátyjának elküldött másolatban Giovanni a korábbi dátumot tüntette fel, és valóban a mi kódexünkön a keltezést tartalmazó sor sötétebb tintával van írva, ami határozottan a későbbi kiegészítés benyomását kelti. Nem valószínű azonban, hogy a dátumon kívül más eltérés is lett volna az általunk és Raffaele által ismert másolat között.

21 Biblioteca Universitaria di Padova Ms. 958, $1^{\mathrm{r}}-2^{\mathrm{v}}$. 
A kézirati szöveg beható tanulmányozása lehetővé teszi annak a megállapítását, hogy a fordító milyen eredeti görög kódexből dolgozott. Meg kell itt jegyeznünk, hogy Raffaele az olvasatok szélesebb körü ismeretével nem ritkán javította vagy kipótolta azokat a szövegrészeket a fordításban, amelyek elszigetelt vagy egyéni olvasatok félreismerhetetlen jegyeit viselték. Ezért az eredeti forráskódex megállapításában csak a kézirat szövege nyújthat biztos támpontot. Ami Raffaele javításait illeti, feltehető, hogy a kódexek nagyobb csoportjához Aldo Manuzio velencei körén keresztül jutott hozzá, amellyel legalábbis 1509-től szoros kapcsolatot ápolt. ${ }^{22}$ Az Aldus-féle Moralia-kiadás (editio princeps) ugyanebben az évben látott napvilágot. ${ }^{23} \mathrm{~A}$ Bruta animalia szövege ebben a kiadásban több egyezést mutat Raffaele javításaival, bár néhol eltérések is vannak. Mindenesetre megfigyelhető, hogy úgy az egyikben, mint a másikban alapvetően, vagy inkább kizárólag, a Planudés-féle kódexek tekintélye az uralkodó, vagyis a П-jelzetű család ( $\alpha \mathrm{AEG}$ ), kiegészülve az ezzel szoros rokonságban álló FJ-ággal. ${ }^{24}$

Ezzel szemben Giovanni fordítása a $\Theta$-család kódexein $(\mathrm{ZuB})$ alapul. ${ }^{25}$ Ehhez hozzávehetjük még szoros rokonsága alapján a b-kódexet is. ${ }^{26} \mathrm{~A}$ legjobb kiindulópontot talán három tulajdonnév egyéni írásmódjából nyerhetjük. A három tulajdonnév a krommyóni koca, a Phikion-hegy, amelyen a Sphinx ül, valamint a teuméssosi róka. A modern

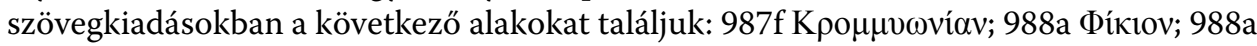

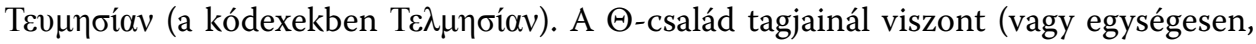

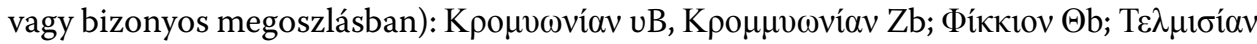

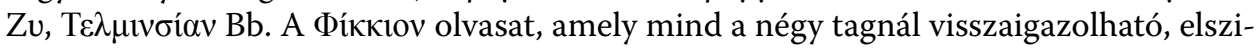
getelten csak erre a családra jellemző. Giovanni fordítása jól tükrözi ezeket a választásokat, amelyek mellé Raffaele kiigazításait is megadjuk: Cromyoniam, Phiccium, Tel-

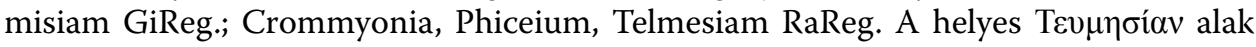
hiánya nem kell hogy meglepetést okozzon, mivel még Dübner sem vezette fel a szövegkiadásába, jóllehet fordításában a Teumesiam alakot adta meg. ${ }^{27} \mathrm{~A}$ Giovanni által használt családot jól behatárolja a Phiccium-fordítás, kiegészülve a többi alakkal, amelyen a család tagjai részlegesen osztoznak.

Nehezebb feladat előtt állunk, ha a $\Theta$-családon belül tovább akarjuk szűkíteni a felhasznált kódexek körét. Biztosan elmondható, hogy az u-kódex kivételével a család többi tagja osztozik egy elszigetelt jelenségben, nevezetesen, hogy a szöveg egy pontján kihagynak egy tagmondatot. Amikor Kirké válaszol Odysseusnak, hogy az állatok visszaváltoztatása nem fog olyan egyszerủen menni, hozzáteszi, hogy azért, mert nem

22 Vö. Pignatti: i. m. (18. jegyz.)

23 Plutarchi Opuscula LXXXXII. Index Moralium omnium, \& eorum quae in ipsis tractantur, habetur hoc quaternione. Venetiis in aedibus Aldi \& Andreae Asulani Soceri, mense Martio, MDIX.

24 A kódexek pontos azonosságához és viszonyaihoz lásd Hubert: i. m. (1. jegyz.) IV skk.; Indelli: i. m. (1. jegyz.) 35 skk. és 47 sk.; J. Bouffartigue: Plutarque, CEuvres morales. Traité 63: L'intelligence des animaux. Paris 2012. LII skk. és LXI skk.

25 Z: Marcianus Gr. 511; v: Vaticanus Urb. Gr. 98; B: Parisinus Gr. 1675.

26 b: Bruxellensis 18967.

27 Vö. Indelli: i. m. (1. jegyz.) 72 (apparatus criticus). 


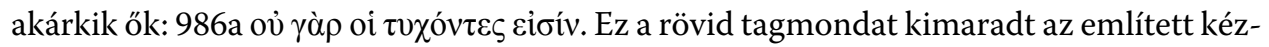
iratokból. De kimarad Giovanninál is, amit persze később Raffaele pótol: Neque enim quilibet sunt e vulgo. Ha ez a tagmondat nem azért maradt ki Giovanni fordításából, mert nem tudott vele mit kezdeni, akkor kényszerüen az a következtetés adódik, hogy az u-kódexnek nem volt a birtokában. Bár fennállhat az az eshetőség is, hogy az olvasatok összevetése során átugrotta a szeme ezt a rövid tagmondatot.

Éppen fordított a helyzet egy másik esetben. A B-kódex elszigetelten kihagyja az egyik tagmondatot, amely arról beszél, hogy Agamemnón a Kópais-tóba merítette tes-

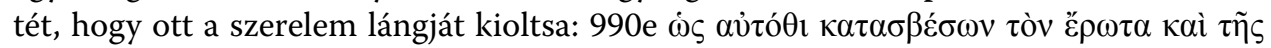
$\dot{\varepsilon} \pi \imath \theta 0 \mu \alpha_{\alpha} \dot{\alpha} \pi \alpha \lambda \lambda \alpha \xi o ́ \mu \varepsilon v o \varsigma$. Mivel Giovanni fordításában ez a tagmondat hiánytalanul megtalálható, ezért csak annyit jelenthetünk ki biztosan, hogy nem ez a kódex volt az egyedüli, amelyet felhasznált a fordításhoz.

A b-kódex egyedüli használatát az zárja ki, hogy másik három társával ellentétben abban a mondatban, amellyel Odysseus elöször Grylloshoz fordul, verbum finitum

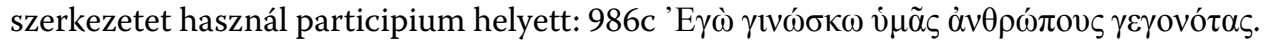
Márpedig Giovanni fordítása olyan forráson alapul, amely a másik használatot részesí-

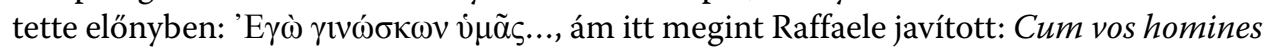
natos esse sciam... GiReg.; Ego vos homines natos esse scio RaReg.

Vagyis az a következtetés adódik, hogy a Bb-kódexek mellett a fordítónak használnia kellett a Zu-kódexpárost, vagy helyesebben legalább a két kódex közül az egyiket. Viszont az v-kódex esetében arra jutottunk, hogy feltehetően nem volt a birtokában. Ezért az tűnik a legvalószínűbbnek, hogy Giovanni egyik fö szövegforrása a Z-kézirat volt, vagy annak egy számunkra ismeretlen másolata. Ez mindenesetre összhangban áll a kódex velencei hovatartozásával.

Egyéb kutatásokból tudjuk, hogy a Bb-kódexek szöveganyaga ma már megragadhatatlan másolatok vagy elveszett apográfok útján eljutott a XV. század végén Padovába és Velencébe. Maga a B-kódex csak 1537-ben, hogy onnan folytassa útját későbbi rendeltetési helyére, Franciaországba. Ám feltehetően létezett egy ezzel rokon ikerkódex is, amelyet Giovanni Calfurnio forgathatott haszonnal - Raffaele Regio gyülöletes ellenfele, aki a Padovai Egyetem katedrájáról elmozdította -, már amennyire azokból a lapszéljegyzetekből megítélhető, amelyeket bizonyos Plutarchos-művekhez írt, és amelyek a B-kódexből ismert olvasatokat tartalmaznak. ${ }^{28}$ A b-kódex akár közvetlenül, akár az a-jelzetű apográfja formájában, ${ }^{29}$ még brüsszeli végállomása előtt szintén felbukkant a korabeli velencei közegben. Giorgio Merula és Niccolò Leonico Tomeo nevét említhetjük azok között, akiknek biztosan dolguk volt ezzel a szöveggel. ${ }^{30}$

Mindezekből könnyen feltételezhető, hogy Giovanni Regio a $\Theta$-család tagjai közül egyszerre többet is szemügyre vehetett. Ha mármost a latin fordítás jellegzetességeire

28 F. Vendruscolo: La Consolatio ad Apollonium fra Mistrà(?) e Padova: apografi quattrocenteschi del Bruxellensis 18967 (b). BollClass 17 (1996) 27 sk.

29 a: Ambrosianus Q 89 sup. (Gr. 689).

30 Vendruscolo: i. m. (28. jegyz.) 4, n. 6 és 24 skk. 
kívánunk áttérni, előtte még számolnunk kell néhány olyan előfordulással, amelyekben nem lehet egyértelműen eldönteni, hogy vajon az eredeti kódex félreolvasásáról, esetleg félreírásról vagy pedig banális fordítási hibáról van-e szó. A félreértések hátterében az erős/gyenge hehezet, a diftongus vagy az iota subscriptum áll.

Gryllos, aki felfedi inkognitóját, elárulja Odysseusnak, hogy emberi életében krétai férfi volt. Amikor Odysseus finom chitónjában és bíbor chlamysében egyszer Krétára látogatott, ${ }^{31}$ elbűvölve a pompás öltözetétől - mint mondja - követte őt, ahogy

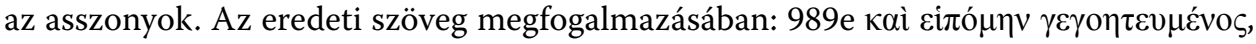

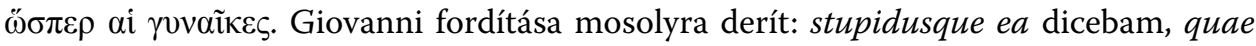
solent mulieres, vagyis elámulva olyan dolgokat mondtam, mint az asszonyok. Raffaele ráakadt a hibára és korrigálta: Te vero sequebar illis stupefactus, neque minus, quam amans mulier attonitus. Természetesen csak az erős/gyenge hehezet váltakozása szül-

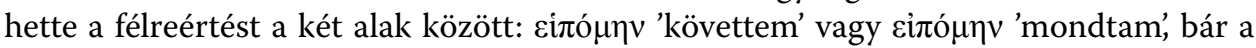
medium használata az utóbbiban ébreszthetett volna némi kételyt.

Egy másik félreértést a szöveg értelme jobban megsínylett. Miután Gryllos a bátorság erényéről bebizonyítja, hogy az állatok jobban a birtokában vannak, Odysseus megkérdezi, miért nem tért át rögtön a mértékletességre. Erre az állati beszélgetőtárs azt feleli, azért, mert azt hitte, hogy előbb meg fogja cáfolni az eddig mondottakat. A szövegben ez így hangzik: 988f "O Giovanni fordítása viszont: Quia putabam te eorum, quae iam dicta sunt, obliturum esse, vagyis mert azt hittem, el fogod felejteni. Raffaele itt is közbelépett, és javította a hibát: Quia putabam te prius, quae iam dicta sunt, refutare velle. A félreértésre az

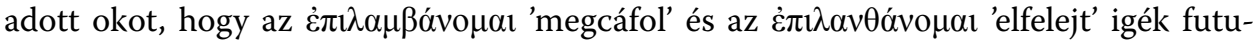
rum infinitivusa csupán egyetlen mássalhangzóban tér el egymástól: غ̇ $\pi \imath \eta \dot{\psi} \psi \varepsilon \sigma \theta \alpha \imath$ vagy $\dot{\varepsilon} \pi \imath \eta \dot{\sigma} \sigma \varepsilon \sigma \theta \alpha$. Az összekeverést okozhatta az eredeti kódex rosszul kiolvasható állapota vagy pedig figyelmetlenség.

A görög kódexekre az iota subscriptum elhagyása gyakran jellemző. Ez természetesen megértési zavarokat szülhet, mint két esetben Giovanninál. Egy alkalommal Gryllos azt ecseteli, hogy a Sphinx sem ment volna sokra a bölcsességével, ha nem múl-

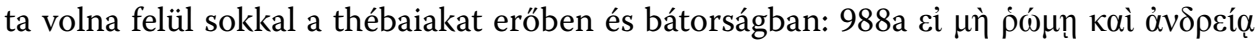

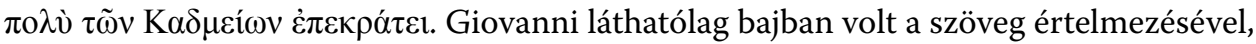
hiszen úgy adta vissza a tagmondatot: nisi virtus ac Thebanorum fortitudo domuisset, azaz ha az erény és a thébaiak bátorsága nem győzött volna. Raffaele viszont átlátta a problémát és helyesbített: nisi Thebanorum plerosque robore viribusque superasset.

Egy másik alkalommal egy határozói alakot értelmez úgy Giovanni, mintha alany-

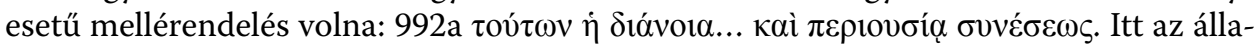
tok értelméről van szó, amely a felfogás bőséges többletével képes a tanulásra. Giovanni fordítása: mens... ingeniique acumen (sc. percipit) nominativus esetet, Raffaele módosított fordítása viszont már ablativus esetet használ: ingenii sollertia (sc. percipiunt).

31 Fikcióból fikciót gyárt Gryllos, hiszen magának Odysseusnak a hamis elbeszélését használja fel, aki saját magát krétai férfinak adta ki. Az eredeti verssorokhoz lásd Hom. Od. XIX 221-235. 
Kérdés, hogy ugyanilyen természetű okoknak kell-e betudnunk azt az alaktani tévesztést is, amelyet nemhogy Raffaele, de még az ő fordítását helyreigazításokkal közlő Stephanus is változatlanul hagyott. Az érintett szövegrészben Gryllos kifejti, ha az emberek nem tartják helyesnek, hogy „értelemről” ( $\lambda$ ó $0 \varsigma$ ) beszéljenek az állatok esetében, akkor ideje volna egy szebb és tiszteletreméltóbb név után nézni, amellyel ezt a képességüket megjelölik: 991f

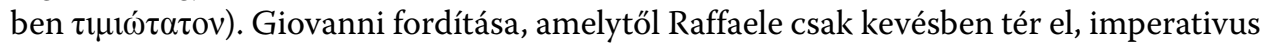
igei alakot olvas a $̋ \rho \alpha$ 'idő' fonnévi alakba: vide, ut excogites ei pulchrius nomen atque honorificentius. A félreértés kiindulópontja nyilvánvalóan a magánhangzó hosszúsága volt, ahogy ez magából a dialógusból is visszaigazolható. Odysseus ugyanis az utolsó megszólalásában felszólítja Gryllost, vigyázzon, nehogy szörnyű erőszakot kövessen el, amikor az istenekről nem tudó állatoknak értelmet tulajdonít. Az eredeti szöveg: 992e

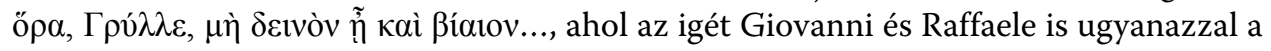
vide alakkal fordítja.

Hogy vajon iskolás hiba vagy pedig szintén a forráskódex nem kielégítő olvasata áll-e egy másik tévesztés mögött, azt nehéz megállapítani. Kétszer is egymás után Gio-

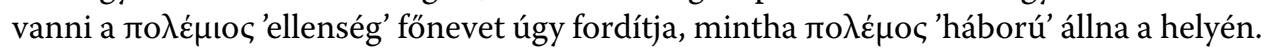

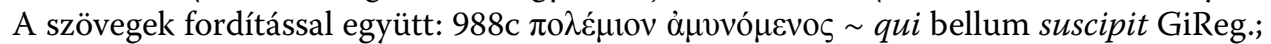

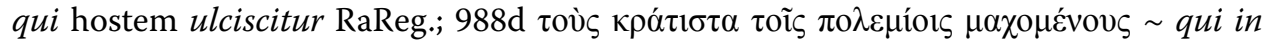
bellis fortissime pugnant GiReg.; qui cum hostibus fortissime pugnant RaReg. Ilyen jellegü hibától azonban éppen a fent idézett helyek egyikén még az Aldus-féle szövegkiadás sem mentes.

A Bruta animalia görög szövegében van néhány sajnálatos szövegromlás, amely az összes általunk ismert kódex egykori archetípusából öröklődött. A modern szövegkiadók birkóznak ezekkel a problémákkal anélkül, hogy érdemi megoldás születne. Természetesen a latin fordítók is szembetalálták magukat ezekkel a szöveghelyekkel, és ki-ki a legjobb képessége szerint igyekezett a legtöbbet kihozni az értelmükből. ${ }^{32}$ Itt most csak egyetlen jellemző példát idézünk a szemléltetés kedvéért. Gryllos egy külön fejezetben bírálta az ember élvezethajhászását az étkezésben, különös tekintettel a húsevésre, amely véres kegyetlenséget követel az embertől azért, hogy hús formájában ínyencséghez (ő\%ov) jusson. Miután a gondolatmenetét befejezte, egy átkötő mondatban elmondja, hogy ezeket az ínyencségeket az emberek pusztán az étel megízesítésére, vagyis élvezetesebbé tételére használják. Azután egy rövid kérdő mondat következik, amelyben

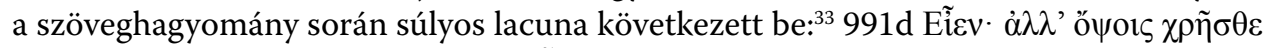

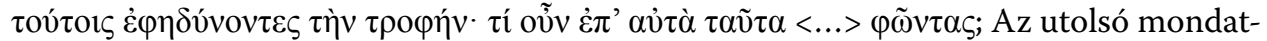
foszlányt Giovanni értelmileg egybevonja a megelőző kijelentéssel: Quid vero obsonia ciborumque condimenta commemorem, vagyis miért emlitsük az ínyencségeket és az ételek ízesítőit? Csakhogy a $\varphi \tilde{v} \tau \tau \alpha \varsigma$ alak nyelvi értelmezése, amely a $\phi \eta \mu$ í 'mond' igé-

32 Néhány ilyen problematikus szöveghely felülvizsgálatára vállalkozott a latin fordítások segítségével a közelmúltban Becchi: i. m. (13. jegyz.).

33 A lacunát már bizonyos kódexek is jelezték; vö. Indelli: i. m. (1. jegyz.) 100 (apparatus criticus). 
ből származtatja, nem tűnik helytállónak. A helyes participium az athematikus igéből $\phi \alpha ́ v \tau \alpha \varsigma$ volna. Ehelyett a modern szövegkiadókkal együtt talán egy $<\tau \rho v>\varphi \tilde{\omega} v \tau \alpha \varsigma$ participium nyomát kell felfedeznünk a csonka alakban. Akkor pedig a kiegészítések egész sorára nyílik lehetőség, ami nagyobb szövegkiesést feltételez, például: Nemde erre a célra <még egy egész mesterséget is kitaláltatok fény>űzésetekben? Említsük meg azonban, hogy nemcsak Raffaele hagyta jóvá ezt a nyelvi értelmezést, hanem a két korábbi latin fordító, Antonio Cassarino és Lampugnino Birago is a mondást kifejező igére aszszociált, amikor a dicetis, illetve dicentes alakokkal adta vissza a fordulatot.

Egy-két esetben a fordító jellemzően görög kifejezésformákat latinosított. Ebben bizonyára figyelembe vette olvasóinak műveltségi szintjét is. Így például a közbevetett vì $\Delta$ í felkiáltást az egyik alkalommal Hercle formában tolmácsolja, a másik alkalommal

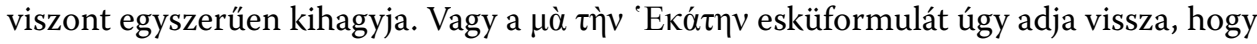
per Proserpinam, amelyet azután Raffaele per Hecaten alakra módosít. Magának a fordítónak a görög kultúrában való tájékozatlanságára utal viszont az a tény, hogy Apollón Ptóios melléknevét elhagyja. Raffaele ebben szintén tanácstalannak tünik, ám merészen behelyettesíti a Pythii (sc. Apollinis) melléknevet. ${ }^{34}$ A kéziratban a kariai asszonyok megjelölésére szolgáló Caieris ragozott alak inkább íráshibának fogható fel a Caricis alak helyett. Ez utóbbi a $\Theta$-család Kapıkàs olvasatából kézenfekvően következik (más kódexekben Kapívas). Raffaele a jobb érthetőség kedvéért a Cariae... feminis körülírást alkalmazza. Máskor egyértelműbb tanúságot tesz Giovanni a görög mitológia ismereté-

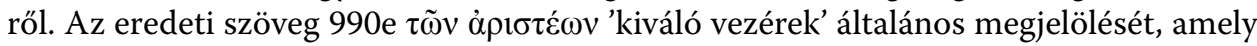
azokra vonatkozik, akiket Héraklés cserben hagyott, automatikusan értelmezi az Argonautarum principes szavakkal.

Nem túl hízelgő egy céltudatos és törekvő fordítóra nézve, ha tévedéseit és hibáit számszerüsítve felsoroljuk. Egy ilyen számvetés nem is biztosan tükrözi az érdemeit. Mindazonáltal elkerülhetetlen, hogy az eredményeket valahogyan összesítsük. A mondatrészek kihagyásának mérlegében Giovanni nem áll nagyon rossz helyen. Körülbelül két-három tucat olyan esetet lehet összeszámolni az egész szövegben, amikor kisebb-nagyobb elemeket szándékosan mellőzött vagy véletlenül átugrott. Biztosan szándékos döntés volt, amelyet stilisztikai megfontolás vezérelt, hogy a feleslegesnek

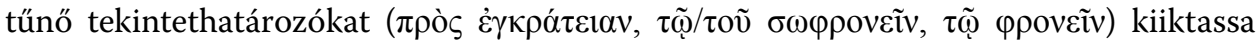
a fordításból. Hasonlóan törölt a fordításból bizonyos töltelékszavakat (oĩ $\mu \alpha 1$, $َ \pi \varepsilon \rho$

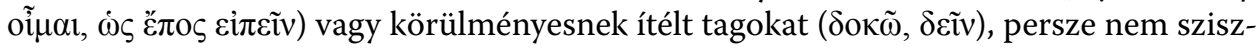
tematikusan. A szövegértés nehézségéből adódóan hiányoznak a fordításból egyes szavak, többnyire olyan mondatokból, amelyeket nem kímélt meg a szöveghagyomány. Talán ezek közé tartozik az a szöveghely is, amelyben Gryllos arról beszél, hogy egy férfi Apollón Ptóios szentélyében titokban felírta a falra, hogy „Achilleus szép”. Itt a görög eredeti 990e $\lambda \alpha \theta \omega ́ v$ olvasata váltakozik a homályos $\mu \alpha \theta \omega ́ v$ olvasattal (a $\Theta$-család egyes

34 Raffaele Regio intuíción alapuló szövegjavítási gyakorlatához, amely Giovanni Calfurnio részéről éles kritikát váltott ki, vö. M. Winterbottom: In Praise of Raphael Regius. In: Antike Rhetorik und ihre Rezeption. Ed. S. Döpp. Stuttgart 1999. 105. 
tagjainál a varia lectio jelölésével), ami elbizonytalaníthatta a fordítót, hiszen egy másik helyen, ahol Odysseusnak arról a félelméről van szó, nehogy Kirké titkon disznóvá vagy farkassá változtassa, a $\lambda \alpha \theta$ oṽ $\sigma \alpha$ participium fordítása nem ütközött akadályba, bár hozzá kell tenni, hogy éppen ezen a helyen Giovanni occulte határozóját Raffaele vala-

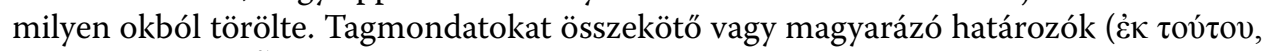

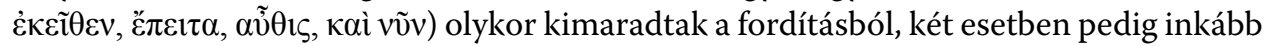

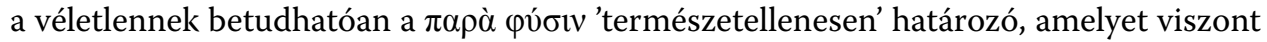
Giovanni a másik két előfordulásában szabályosan a praeter naturam szavakkal lefordít. Fennmarad ezek után két eset, amelyekben egy-egy jelzőt hiányolhatunk a fordításból. Az egyikben Agamemnón szép testét szépen a Kópais-tóba meríti, ami láthatólag sok volt Giovanninak, ezért pusztán annyit írt: in Copaida paludem se ipsum pulcherrime iniecit, meghagyva Raffaelének, hogy a formosus kiegészítést megtegye; a másikban pedig két jelző közül egy maradt el, ahol a kívülről behozott és felesleges vágyakról beszél a szöveg, viszont a fordításban csak a superfluas alak szerepel. Itt ismét Raffaele pótolta a hiányt az externas... ac invecticias dupla kiemeléssel.

Egyébként Giovanni fordításában mintegy öt-tíz alkalommal találkozunk hen-

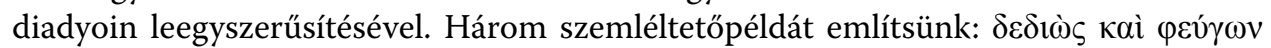

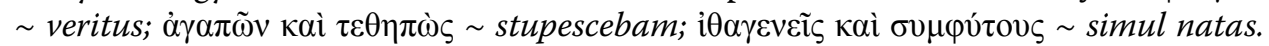
Raffaele ezeket a példákat érintetlenül hagyta. Jellemzőbb azonban a fordításra, amikor

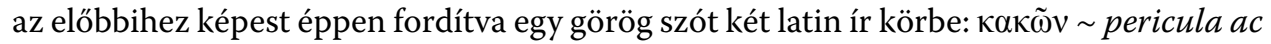

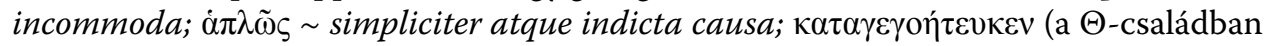

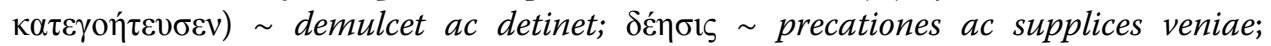

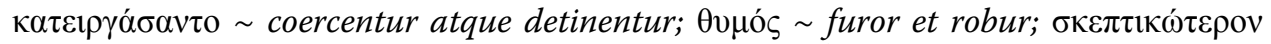

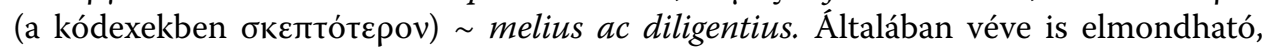
hogy Giovanni inkább arra törekszik elődjével, a nagyon szorosan fordító Lampugnino Biragóval szemben, hogy a szöveget körbeírásokkal, magyarázó kiegészítésekkel, illetve lazább szövegkövetéssel érthetővé tegye. Körülbelül félszáz olyan esetet számolhatunk össze, amikor egy adott elem a görög szöveg megfogalmazásában többszavas szerkezetekben jön vissza a latin fordításban. Ide kell értenünk nemcsak a kiegészítő határozók beszúrását (semper, olim, maxime, facile stb.), hanem az aoristosi és imperfectumi igeaspektusok vagy a szokásszerűség kifejezésére irányuló törekvéseket is. Például: $\pi \varepsilon i ̃ \sigma o v$

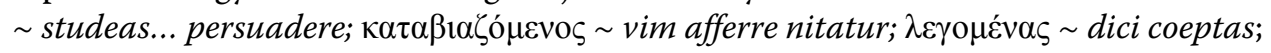

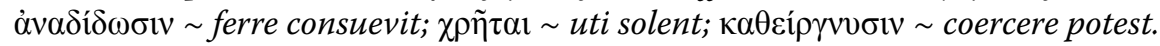

Minden tiszteletünket fenntartva a fordító iránt azért a kísérletéért, hogy a Bruta animalia amúgy nehéz és nem problémamentes szövegét átadja egy idegen nyelven, mégsem feledkezhetünk meg a tévesztésekről: a félreértett szavakról és a rosszul összerakott mondatszerkezetekről. Az iskolás hibák kategóriájába sorolhatjuk azokat a tévesztéseket, amelyekben a tranzitív/intranzitív jelentés, a középfok/felsőfok vagy az idő-/helyha-

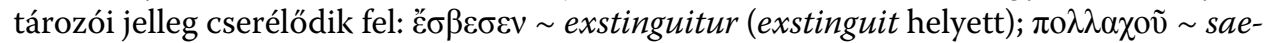
penumero (a $\pi \mathrm{o} \lambda \lambda \alpha \alpha_{\kappa} \iota \varsigma$ értelmében); $\pi \lambda \varepsilon i ́ \sigma \tau \omega \nu \sim$ pluribus. Raffaele csak a legutóbbiban javított plurimis alakra. Nagyjából tíz-tizenöt esetben az eredeti görög szó jelentésének ismeretében mutatkozik fogyatékosság. Az enyhébb esetek között említhetjük, amikor a 


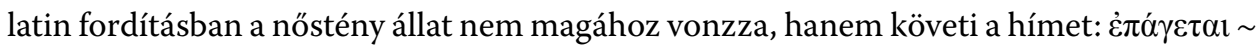
sequuntur; vagy amikor Agamemnón nem a tengerre és a szelekre fogja hamisan a Trójából való késlekedést, hanem ezek meghiúsítják vagy rászedik: $\kappa \alpha \tau \alpha \psi \varepsilon v \delta o ́ \mu \varepsilon v o \varsigma \sim$ frustratus (mintha passivum volna); illetve amikor Gryllos az aranyat és az ezüstöt, ahogy a többi követ, nem átlépi a lábával, hanem tapossa: vं $\varepsilon \rho \beta \alpha i ́ v \omega \sim$ conculco. A teuméssosi róka a sajátos $\mu \varepsilon ́ \rho \mu \varepsilon \rho o v ~ \chi \rho \tilde{\eta} \mu \alpha$ 'komisz pára' megjelölést viseli, amely valószínüleg egy irodalmi mủből van kölcsönözve, ennek jelzői tagját Giovanni a curiosam 'gondos' alakkal adja vissza nem teljesen ok nélkül (vö. $\mu \varepsilon \rho \mu \nu$ ó $\omega, \mu \varepsilon \rho \mu \eta \rho i ́ \zeta \omega)$, de Raffaele kipontosít-

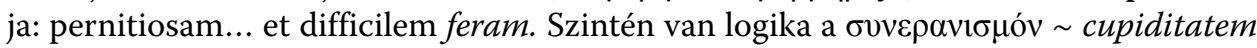

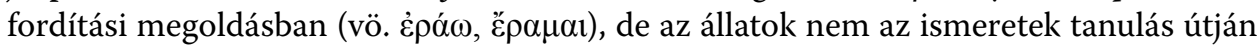
való vágyának, hanem az innen-onnan való összegyűjtésének mondanak búcsút csodás képességük révén. Gryllos szemére veti Odysseusnak, hogy nem rejti el arcát szégyenében, amikor az eposzi jelzőkkel „bátornak” és „városdúlónak” nevezik, holott a harcban csak a cselt és a ravaszságot ismeri. Giovanni talán a medium igei alak elrejtőzés értelméből kiindulva félrevezetődik, mintha a szöveg azt akarná mondani, hogy nem vagy

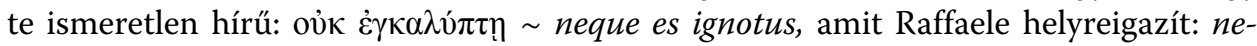
que perfricas frontem. Kirívóbb esetekben már visszakövethetetlen a fordító szándéka. Ilyen az, amikor a szagok kipárolgását valamilyen megfontolásból töréseknek értelmezi:

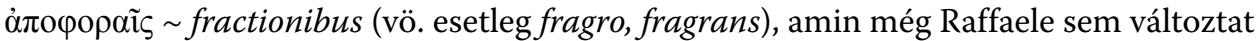
sokat: quae fracta movent odoratum. De talán az összes közül a legmeglepőbb választás abban a részben található, amely az állatok cirkuszi bemutatókon való ügyességét tárgyalja. Itt azt sorolja el Gryllos, hogy tanulékonyságuk bizonyítékaként az állatok talajra fekvéseket, kartáncokat és veszélyes felállásokat mutatnak be. A felsorolás utolsó tagja az eredeti szövegben $\sigma \tau \alpha ́ \sigma \varepsilon ı \varsigma$, amely persze a leggyakoribb előfordulásában a felkelést vagy lázadást jelenti. Giovanni fordítása: seditiones periculosas meglepő, mert a cirkuszi bemutatókon az állatok részéről nehéz lázadást elképzelni. Lehetséges, hogy a veszélyes állatviadalok jártak az eszében, amikor e fordítás mellett döntött. Raffaele helyesen változtatja az értelmet felágaskodásra: in pedes monstrosas erectiones.

A félreértett mondatszerkezetek túlságosan részletekbe menő tárgyalása messzire vinne minket célunktól. Néha előfordul, hogy Giovanni a határozókat nem a megfelelő helyre rendeli. Egy látványos esetben Odysseus a $\mu \tilde{\alpha} \lambda \lambda$ ov határozóval azt fejezi ki, hogy jobban szereti és vonzódik a saját rögös Ithakájához, mint a kyklópsok önmagától

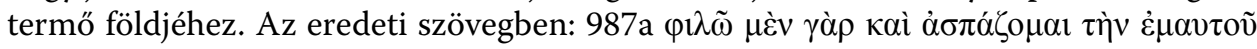
$\pi \alpha \tau \rho i ́ \delta \alpha \kappa \alpha i ̀ ~ \chi \omega ́ \rho \alpha \nu \mu \tilde{\alpha} \lambda \lambda o v$. A határozó hátravetett helyzete megtéveszthette a fordítót, akinél azt olvassuk: meam ipsius patriam ac potius regionem et amo et amplector, vagyis a saját hazámat, sőt inkább vidékemet szeretem is, vonzódom is hozzá. A helyes hozzárendelést Raffaele fordításában találjuk: meam ipsius patriam et agrum magis et amo et amplector. Többször az eredeti görög kódexek központozásának hiányából vagy hanyagságából fakadóan a tagmondatok szétválasztása nem a legszerencsésebb helyeken történik, ami kisebb-nagyobb értelmi fennakadásokat okoz. Itt figyelembe kell vennünk, hogy Plutarchos szeret hosszú és többszörösen összetett mondatokat használni, amelyeket a tagolást jelző központozás híján nem kis teljesítmény követni. Ha 
tehát nagyjából öt alkalommal Giovanni, akár az értelem rovására is, a ma elfogadott mondattagolással ellenkező irányban halad, nem megbocsáthatatlan vétség. Valójában a kisebb figyelmetlenségből származó fordítási hibákon kívül csupán egy-két esetben van súlyosabb félrefordítás, amely egész mondatot érint. Kiemelt példaként említhetjük ismét a cirkuszi állatokkal foglalkozó részből a bevezetőmondatot. Gryllos azt mondja, azoknak az állatoknak, amelyeket az emberek fényűzésből vagy szórakozásból rávesznek arra, hogy tanuljanak és gyakoroljanak, az értelmi képessége kitűnően elsajá-

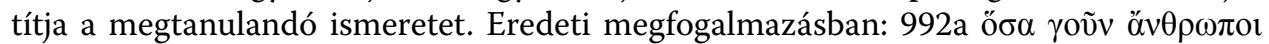

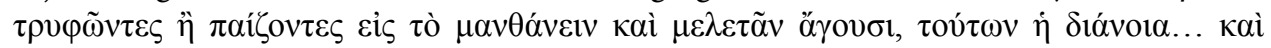

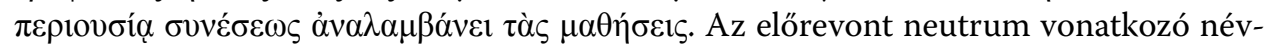
más bizonyára megzavarhatta Giovannit, ezért azt a tanulás és gyakorlás élettelen tárgyának vette, amelyre azután a fölérendelt mondat mutató névmása vonatkozik, vagyis mindazokat a dolgokat, amelyeket az emberek megtanulnak és gyakorolnak, azoknak a mi értelmünk (ti. az állatoké) és éles szellemi képességünk a megtanulását könnyen elsajátítja: Quaecumque igitur homines deliciis incumbentes ludentesve discunt atque meditantur, eorum mens nostra... ingeniique acumen facile percipit disciplinas. A mondat helyes értelmét itt is Raffaele adta meg: Quascumque igitur ferarum homines in deliciis lusibusque habentes docent ac exercent, eae... facile percipiunt.

A továbbiakban két irányba teszünk kitekintést. Előbb nagy vonalakban megvizsgáljuk, milyen mértékben és milyen alapelvek szerint vetette alá revíziónak Giovanni fordítását Raffaele, azután pedig megpróbálunk választ adni arra a kérdésre, hogy vajon Giovanni felhasználta-e a saját fordításához elődeinek munkáját.

Talán nem árt rögtön tisztázni, hogy a szerzői jog mai felfogásával ellentétben a testvérbáty bizonyára nem érezte aggályosnak, hogy elhunyt öccsének munkájába beleavatkozzon. Abban a meggyőződésben tehette ezt, hogy testvére fordítói érdemeit fogja gyarapítani, hiszen a Bruta animalia kinyomtatott fordítását egyedül Giovanni nevével kísérte. Bár a beavatkozás igen nagymértékű, a társszerzőség feltüntetését elkerülte.

Már több ízben volt alkalmunk megfigyelni, hogy Raffaele az eredeti görög szöveg pontosabb megértésével, sőt más olvasatok bevonásával is, sikeresen javította Giovanni fordítását. A kézirati szöveg és a javított, nyomtatott változat tüzetes egybevetéséből úgy becsüljük, hogy a korrekciók közül nagyságrendileg ötven tekinthető határozottan eredményesnek, beleértve a kihagyott nyelvi alakok pótlását. További ötven-ötven esetről elmondható, hogy Raffaele vagy a szűkítő pontosítás igényével, vagy a bővítő magyarázat szándékával járt el, bár ezekben az esetekben nem mindig egyértelmű, hogy a szöveg javára történt a módosítás. Az első csoportban több szavas kifejezések egyszerűvé alakításával, egyes/többes számok kiigazításával, képzők, igekötők, esetviszonyok, elöljárószók pontosításával találkozunk. A második csoportban viszont maga Raffaele érezte úgy - önmagával is némileg ellentmondásba kerülve -, hogy az egyszerű alakokat jobban körül kell írnia, vagy el kell látnia további bővítményekkel.

Nem szabad megfeledkeznünk arról sem, hogy körülbelül húsz-húsz esetben Raffaele nem javította ki a félreértést, illetve nem pótolta a hiányzó nyelvi alakokat. Végül több mint húsz esetben változtatás történt ugyan, de a szöveg értelme nem feltétlenül lett jobb ezáltal, vagy került közelebb az eredetihez. Gryllos érvelésében például 
az állatok bátorsága azért magasabb rendű az emberekénél, mert bennük keveretlenül van jelen az „indulat” ( $\theta v \mu$ ó $)$, amely a bátorságnak mintegy a megedzése és éle. Ahogy

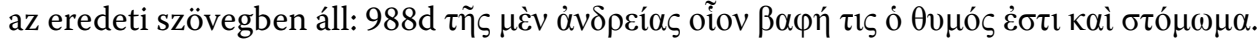
Giovanni fordítása a tanácstalanságát tükrözi: fortitudinis quidem ut tinctura quaedam est furor et robur, de Raffaele sem kínál sokkal jobb megoldást, még ha pótolja is a hendiadyoin második tagját: fortitudinis velut temperatura quaedam et consolidatio est animi impetus. Egy másik szöveghelyen Gryllos arról kérdezi Odysseust, vajon a kyklópsok önmagától termő földjét tartja-e jobbnak, vagy a rögös Ithakát. Figyelmezteti, nehogy rossz néven vegye, és a hazája iránti jóindulatból mást feleljen, mint amit

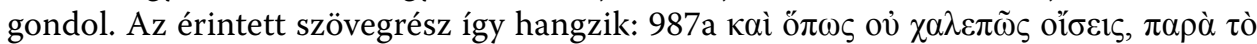

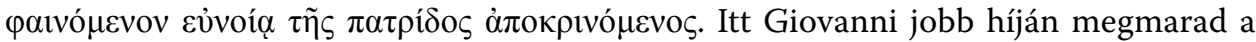
szó szerinti fordításnál: Et quonam modo non turpiter feres, si aliter ac sentis, patriae benevolentia respondebis? Ám nem úgy tűnik, mintha Raffaele a szavak átfogalmazásával jobban megragadta volna az értelmet: Et quo modo tibi grave non erit, si praeter sententiam caritate patriae responderis? Különös módon még arra is találni példát, hogy Raffaele egy amúgy helyes alakot tévesen vet alá javításnak. Gryllos a dialógus során kétszer használja az oľ $\sigma \theta \varepsilon$ igei alakot általánosan az emberekre vonatkozóan, miközben Odysseusszal beszélget. A mondat szerkezete hasonló mindkét esetben: ha ti, emberek, úgy gondoljátok, hogy... Míg a két előfordulás közül az elsőben Raffaele meghagyja a Giovanni által használt többes számot, addig a másodikban egyes szám-

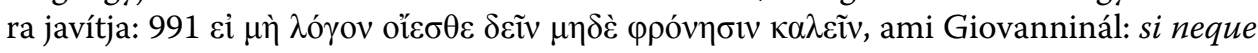
rationem, neque prudentiam nominandam putatis, Raffaelénél viszont: si neque rationem, neque prudentiam nominandam putabis. Ez a változtatás bizonyos fokú elhamarkodottságra utal.

Valójában Raffaele az öccse szövegét erősen átírta. Ez mindaddig nem is ötlik a szemünkbe, amíg közvetlenül nem helyezzük egymás mellé az egyes mondatrészeket. Nevezhetjük stilisztikai átdolgozásnak is, ami azt feltételezné, hogy az idősebb és tapasztaltabb testvér az eredeti fordítást nem tartotta kellően érettnek. Mégis nehezen kerülhető el az a benyomás, hogy valamilyen tekintélyi elv alapján szinte mindent javított, amit lehetett. A mélyebb analízis legalábbis felfed bizonyos ellentmondásokat. Míg ugyanis egyszer az irrides ragozott igét illudis alakra módosítja, addig máskor éppen az illudendam gerundivumot változtatja irridendam alakra anélkül, hogy világosan látnánk a különbség okát. Ugyanígy jár el a foret és esset, illetve essent és forent igei alakok cseréjével, holott amennyire tudni lehet, a létigének e két alakja között pusztán formai a különbség. A kötőszóknál és határozószóknál kitapintható valamiféle érzékenysége, amennyiben más kötőszók helyett inkább részesíti előnyben a sed használatát, de míg például a modo határozót többször is felcseréli a szebbnek vagy jobbnak ítélt solum alakra, addig, amikor solum van a szövegben, akkor ő maga javít a modo határozóra. Ugyanígy szám szerint ugyanannyiszor javítja ki a fordításban az autem kötőszót a rokon értelmü vero alakra, mint a vero kötőszót autem alakra. Vagyis ha nem egy magasabb stílusérzék indokolja ezeket a változtatásokat, akkor inkább rossz beidegződésre gyanakodhatunk. Természetesen ezzel nem állítjuk, hogy Giovanni fordításában bizonyos elemek ne szorulnának korrigálásra. 
Raffaele javítási módszerének a szemléltetése céljából közlünk néhány válogatott példát az egyes nyelvi kategóriákból. Az alábbi kötőszókra, határozószókra és névmásokra vonatkozó példák általános hajlamot jeleznek:

$\begin{array}{ll}\text { GiReg. } & \text { RaReg. } \\ \text { at, autem } & \text { sed, vero } \\ \text { atque, ac } & \text { et } \\ \text { aut } & \text { vel } \\ \text { enim } & \text { nam } \\ \text { vero, verum } & \text { sed, autem } \\ \text { ita } & \text { sic } \\ \text { modo } & \text { solum } \\ \text { quoque } & \text { etiam } \\ \text { is } & \text { ille } \\ \text { hic } & \text { ille, iste }\end{array}$

A névszókra és igékre vonatkozó példák egyéni előfordulásokat takarnak. Olyanokat gyüjtöttünk ki, amelyeknél a szinonimák megválasztása nem tükröz lényeges jelentéskülönbséget:

$\begin{array}{ll}\text { GiReg. } & \text { RaReg. } \\ \text { benevolentia } & \text { caritate } \\ \text { care } & \text { dilecte } \\ \text { cupiditati } & \text { libidini } \\ \text { feris } & \text { brutis } \\ \text { flumine } & \text { torrente } \\ \text { longis } & \text { diuturnis } \\ \text { opinionem } & \text { sententiam } \\ \text { pugnis } & \text { proeliis } \\ \text { regione } & \text { terra } \\ \text { speciem } & \text { genus } \\ & \\ \text { aboleantur } & \text { perdatur } \\ \text { appellant } & \text { vocant } \\ \text { contemnimus } & \text { despicimus } \\ \text { decet } & \text { oportet } \\ \text { dicitur } & \text { memoratur } \\ \text { festinas } & \text { properas }\end{array}$




$\begin{array}{ll}\text { foret } & \text { esset } \\ \text { interficiuntur } & \text { interimuntur } \\ \text { irrides } & \text { illudis } \\ \text { iudicatur } & \text { putatur } \\ \text { nitatur } & \text { conetur } \\ \text { oravi } & \text { supplicavi } \\ \text { permittit } & \text { sinit } \\ \text { praestabo } & \text { exhibebo } \\ \text { probantur } & \text { monstrantur } \\ \text { putatis } & \text { sentitis } \\ \text { studeas } & \text { coneris } \\ \text { superantur } & \text { domantur } \\ \text { timent } & \text { horrent } \\ \text { vides } & \text { spectas }\end{array}$

Talán ebből a néhány példából is látható, hogy Raffaele a szöveg mélyszerkezetének lehetőség szerinti megtartásával úgy formálta át a fordítást a saját ízlésének és vélt vagy valós stiláris követelményeknek megfelelően, hogy jóval túllépett a mai értelemben vett lektor hatáskörén. Szinte látjuk, ahogy a birtokában lévő kéziraton lázasan dolgozva azáltal képes a sajátjává tenni a több szempontból kiigazításra szoruló nyersanyagot, hogy új, eleven tartalmakkal tölti meg a mondatrészeket. Ennek a müveletnek a során azonban önkéntelenül a kelleténél nagyobb beavatkozást eszközölt munkájának tárgyán.

Miután Giovanni fordításának utótörténetébe a bátyja munkásságán keresztül betekintést nyertünk, feltehetjük a kérdést, hogy vajon két elődjének, Antonio Cassarinónak és Lampugnino Biragónak a fordításait felhasználta-e az ifjú. Ezek a fordítások kéziratokban voltak hozzáférhetők. A ma rendelkezésünkre álló kódexek tanúsága alapján az előbbi legalább három, ${ }^{35}$ az utóbbi két kéziratban. ${ }^{36}$ Mindketten a Moralia darabjainak egy-egy kisebb csokrát ültették át latinra, a művek közé választva a Bruta animalia című dialógust. Antonio Cassarino szövegével Giovanni fordítása kevés azonosságot mutat, bár gyanút ébreszt néhány fordulat kísérteties hasonlósága a szicíliai fordító ajánlásával. Hacsak nem az ajánlás általánosan bevett fordulatairól van szó, feltűnő, hogy Cassarino is mentségül a szerény felajánlásért arra hivatkozik, hogy szívéből mindenét át kívánja adni a címzettnek (quam omnia in te conferre cupiam), illetve az érdemeit próbálja csökkenteni azáltal, hogy elmondja, a fordítást a legrövidebb éjjeli munkával (brevissima lucubratiuncula) készítette el. ${ }^{37}$ Giovanni hasonlót mond, amikor arról beszél, hogy gyakorlás kedvéért (exercitationis gratia) fordította le a múvet.

Egészen más a helyzet Lampugnino Birago szövegével. Noha első pillantásra a mondatszerkesztés alapvetően eltérő jellege miatt nem gondolnánk szoros rokonságra,

35 Vat. lat. 3349, 44v $-53^{\mathrm{v}}$; Casanat. 665 (C II 8), 56r $-62^{\mathrm{v}}$; Ms. Lodi XII E 13, 32 $-36^{\mathrm{r}}$.

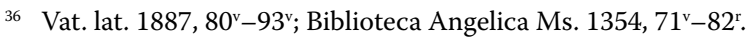

37 Mármint pusztán az insinuatio értelmében, hiszen valójában ezzel az érdemeit növeli. 
mégis alaposabb szemügyre vétel után kétely fogalmazódik meg, ami lassan bizonyossággá érik. A tények összesítése nagyon erősen amellett szól, hogy Giovanni a fordításban használt latin szókészletének jelentős részét Biragótól merítette. Birago fordítása tulajdonképpen a görög eredetit nagyon szorosan követő „árnyékszöveg”, amely a görögül és latinul egyaránt tudó olvasó számára lehetővé teszi, hogy szóról szóra visszakövesse az eredeti alakokat. Vagyis ez a fordítás egyszerre tölti be a szótár szerepét, és szolgál nyelvtani útmutatóul a szöveghez, amelyből alaktani, mondattani és jelentéstani ismeretek nyerhetők. Giovanni a fordításában ezzel szemben szabadabb elveket követ. Tartja magát ugyan az eredeti szövegvezetéshez, ám lépten-nyomon érezhető, hogy a mondatait igyekszik a latin nyelv szabályai és törvényszerűségei szerint alakítani. Ebből a szempontból átmenetet képez Antonio Cassarino elnagyoltabb és Birago iskolásan pedáns szövege között. Mindez azonban nem jelenti, hogy nem hívhatta segítségül Birago fordítását a Bruta animalia szövegének feldolgozása során. Olyan árulkodó jelek nyomába kell tehát erednünk, amelyek megerősítik a feltevésünket.

A példák között a közös hibák vagy az olyan mindkét fordításban megtalálható jellegzetességek jöhetnek szóba, amelyek nem magyarázhatók más okokkal, akár a szóhasználat, akár a mondatszerkesztés területéről valók.

Birago abban a fejezetben, ahol Gryllos a vágyak epikureus filozófiából ismert fel-

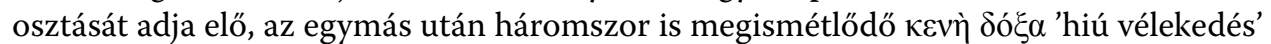
szókapcsolatot következetesen az inanis gloria fordítással adja vissza. Ez félreértésből adódik, hiszen az állatok, amelyek a vágyaikban a mértékletességet követik, nem a „hiú dicsőségtől”, hanem a „hiú vélekedésektől” mentesek az epikureus filozófiai terminológiával összhangban. Ezt Giovanni helyesen felismerte, ezért az opinio alakkal fordít. Mégis egy alkalommal váratlanul belopakodik a szövegbe az inanis gloria fordítás: 989c

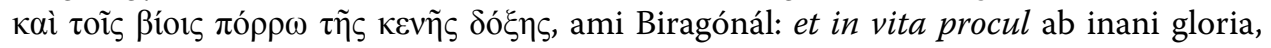
Giovanninál pedig: ac in ipso victu longe ab inani gloria. Minthogy Giovanni az össszes többi előfordulásban - még az említett fejezeten kívül is - a saját terminológiáját követi, ezért nehéz másra gyanakodni ebben az esetben, mint Birago szövegének véletlen, tudat alatti befolyására.

Egy másik szövegrészben Gryllos a kyklópsok földjéről beszél, amelyről megállapítja, annyira jó és nemes természetü, hogy minden termést megterem önmagától: $986 f$

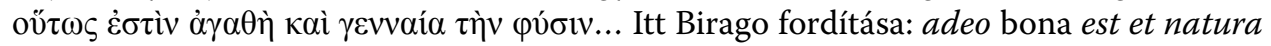
generosa, amihez képest Giovanni csak kevéssé tér el: sola bonitate ac generositate ingenita. A bökkenő csupán az, hogy a $\Theta$-család szöveghagyományában, amelyből Giovan-

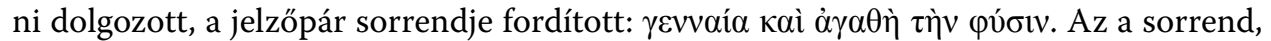
amelyet Birago követett, a Planudés-féle kódexekre jellemző, ezeket viszont Giovanni biztosan nem ismerte.

Az állatok tanulékonyságának bizonyítékai között említi Gryllos azt a megfigyelést, hogy a csalogányfiókák, ha fogságban nevelkednek, nem tanulnak meg olyan szépen énekelni, mint vadon élő társaik. Az érvelés szerint a fiókák helyzete ahhoz hasonlít, mintha

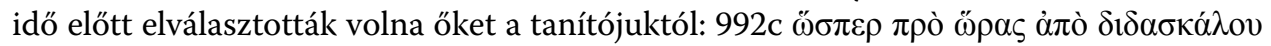

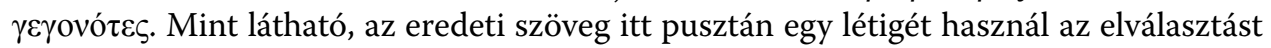


kifejező határozó mellett. Annál különösebb a latin kifejezések hasonlósága, amelyekhez az egyik és a másik fordító folyamodott. Míg Birago: ut ante tempus a magistro abstractae, addig Giovanni: ut qui ante legitimum tempus a praeceptore subtracti sint. Nehéz megállapítani, mekkora esélye van annak, hogy két latin fordító egymástól függetlenül rátaláljon a traho ige melléknévi igenevére. Mindenesetre visszaellenőrző példaként idézhetjük Cassarino fordítását: tamquam intempestive a magistro sint amoti.

Fontos megjegyezni, hogy Birago szoros fordítási módszerének szelleméhez hűen nem ritkán etimológiai szempontokat helyez előtérbe a görög szavak fordításában, olykor akár még a jelentés rovására is. Ennek az eljárásnak kirívó példáit nyújt-

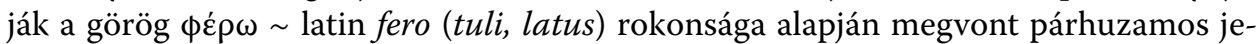

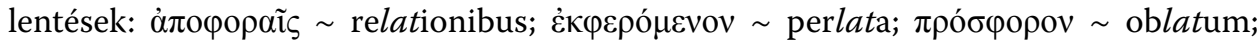

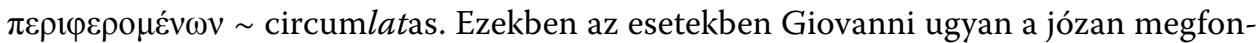
tolást követve a szöveg értelméhez jobban illeszkedő alakokat választott, máskor minden jel szerint csatlakozott elődjéhez, nyilván azért, mert úgy ítélte, hogy az etimológiai szempont és az értelem nem ütközik össze egymással. Az alábbi példák ezeket az eseteket tartalmazzák, még ha egy-kettő közülük kizárólagos érvényét veszíti is azáltal, hogy Cassarino fordításával is egyezik: ${ }^{38}$

\begin{tabular}{|c|c|c|c|}
\hline & Bir. & GiReg. & Cass. \\
\hline 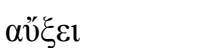 & auget & auget & alit \\
\hline$\dot{\alpha} \varphi \varepsilon ́ \sigma \tau \eta \kappa \varepsilon \nu$ & distat & praestat & distet \\
\hline$\delta 1 \alpha \pi \alpha \sigma \mu \alpha ́ \tau \omega \nu$ & diapasmatum & pastillis & odorum \\
\hline$\dot{\varepsilon} \gamma \nu \omega \kappa \omega ́ \varsigma$ & cognoscens & cognoscat & inveniens \\
\hline$\varepsilon \dot{\varepsilon} \kappa \varphi \varepsilon ́ \rho \varepsilon \imath$ & effert & effert & fert \\
\hline$\varepsilon \mu \pi i \pi \lambda \eta \sigma \imath$ & implent & implent & implicant \\
\hline$\theta \eta p i ́ o v$ & fera & fera & belua \\
\hline 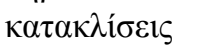 & inclinationes & inclinationes & $\varnothing$ \\
\hline$\mu \eta \chi \alpha \nu \alpha \tilde{\imath} \varsigma$ & machinamentis & machinationibus & $\varnothing$ \\
\hline 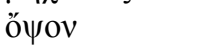 & obsonium & obsonium & pulmentum \\
\hline 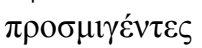 & $\operatorname{admixti}$ & permixti & admoti \\
\hline$\pi \rho \circ \delta^{\prime} \omega \kappa \varepsilon$ & prodens & prodidit & prodidit \\
\hline$\sigma u ́ \gamma \chi v \sigma ı v$ & confusionem & confusionem & confusionem \\
\hline$\sigma u \mu \varphi \varepsilon ́ \rho \varepsilon \tau \alpha \imath$ & conferuntur & feruntur & coeunt \\
\hline
\end{tabular}

38 A Cassarino fordításával való egyezés a dolog természetéből adódóan sem bizonyító-, sem cáfolóerővel nem bír. 
Néhány további eset, ha nem is szigorú értelemben vett etimológiát, de legalábbis a tövek komoly nyelvészeti szintű értelmezését feltételezi:

\begin{tabular}{|c|c|c|c|}
\hline & Bir. & GiReg. & Cass. \\
\hline$\dot{\alpha} v \alpha \lambda \alpha \mu \beta \alpha \dot{v} v \varepsilon 1$ & suscipit & percipit & addiscit \\
\hline$\beta \alpha \varphi \eta ́$ & intinctio & tinctura & iuvatur \\
\hline$\varepsilon ँ \pi \eta \lambda v \varsigma$ & adventicia & advena & externa \\
\hline$\pi \varepsilon \rho^{\prime} \beta \lambda \varepsilon \pi \tau \circ \varsigma$ & circumspectus & conspicuus & gloria \\
\hline$\dot{\rho} \varepsilon v ́ \mu \alpha \tau o \varsigma$ & fluxu & flumine & torrente \\
\hline 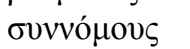 & compascentes & legitimos & suos \\
\hline
\end{tabular}

Úgy tűnik, hogy az utolsó példában Giovanni helyesbítette a nyelvi alak származtatását, a tévesnek ítélt vo $\mu$ ó ৎ 'legelő' helyett a vó $\mu$ oc 'törvény' alakra vezetve vissza az eredetét.

Az általános szóhasználati egyezések Birago és Giovanni fordításában igen nagyszámúak. Az összes nyelvi alakot (névszók, igék, határozók) számításba véve körülbelül kétszáz olyan előfordulásról beszélhetünk, amelyben a két fordító szóválasztása teljesen azonos vagy majdnem azonos, és szemben áll Cassarino fordításával. ${ }^{39}$ Jellemző például, hogy a dialógusban kulcsfontosságú $\delta 1 \alpha \lambda \varepsilon ́ \gamma o \mu \alpha$ 'párbeszédet folytat, vitatkozik' igét Giovanni és Birago minden előfordulásában egységesen a disputo igével és származékaival fordítja, míg Cassarino a dissero, rationibus certo, illetve alloquor igék között váltakozik attól függően, hogy mi felel meg a szövegösszefüggésnek. Hasonlóan a görög oĩ $\alpha$ ' 'gondol' ragozott alakjait Birago és Giovanni mindvégig a puto igével fordítja, ezzel szemben Cassarino a video, arbitror, credo és consentio változatokkal adja vissza. De ugyanez a megfigyelés érvényes az dơ $\alpha \pi \alpha ́ \omega$ 'szeret' igére is, amely Biragónál és Giovanninál minden esetben az amo igével van fordítva, ám Cassarinónál egyszer sem, hanem az antepono és diligo alakokkal.

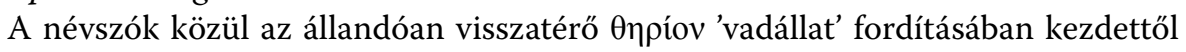
fogva megoszlás tapasztalható, amennyiben Giovanni és Birago túlnyomórészt megmarad a fera használata mellett, Cassarino pedig a belua mellett, de az utóbbinál sokkal nagyobb az ingadozás a rokon értelmü animalia, bruta és fera szavakkal, miközben a másik oldalon egyedül Giovanni újít azzal, hogy három szöveghelyen bevezeti a bruta alakot, amelynek a számát azután Raffaele négyre növeli. Ez a változtatás is Birago masszív szóhasználatához képest bizonyítja, hogy ő volt Giovanni kiindulása. Az ani-

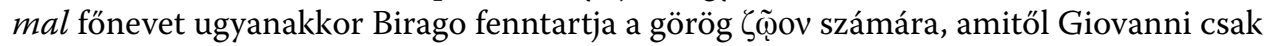
egyetlen ízben tér el. A másik szemléltető erejü példa a görög $\lambda o \gamma \downarrow \sigma \mu o ́ c$ 'számítás, logikai képesség' szó lehet, amelynek Cassarinónál még láthatóan nincs meg a szakterminusjellege, mivel egyszerűen a cogitatio és ratio szavakkal fordítja, Birago és Giovanni vi-

39 Nagyjából fele annyi esetben Birago és Giovanni szóválasztása megegyezik ugyan, ám az érv erejét kioltja a Cassarino fordításával való hasonlóság vagy egyezés. 
szont már a ratiocinatio kifejezést használja úgy magára a főnévre, mint igei származékára. Szintén egyéni jellegü, és ezért közös eredet mellett tanúskodik a görög $\varphi \imath \lambda o \tau \imath \mu$ í

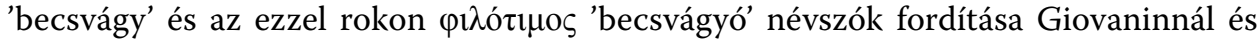
Biragónál, akik ezeket az ambitio és ambitiosus szavakkal adják vissza, szemben Cassarinóval, aki a studium és prudens szavakat használja.

Egy összesítő táblázatban válogatjuk össze a további példák közül azokat, amiket elég jellemzőnek találunk ahhoz, hogy Giovanni és Birago szövegének rokonságát bizonyítsák. A példákat a névszók, igék és határozók kategóriájából egyaránt merítjük:

Bir. GiReg. Cass.

\begin{tabular}{|c|c|c|c|}
\hline 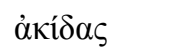 & spicula & spicula & ferrum \\
\hline$\not \alpha \mu$ орор & expers & expertem & destitutus \\
\hline$\pi \alpha ́ \tau \alpha \varsigma$ & deceptiones & deceptiones & fraudes \\
\hline dov & inhonorum & inhonoratam & turpem \\
\hline oípovs & insolubilia & nodos insolubiles & ambages \\
\hline$\eta \sigma 1 \varsigma$ & preces & precationes & supplicant \\
\hline$\delta \omega \lambda \mathrm{ov}$ & simulacrum & simulacrum & umbram \\
\hline & indigens & indigentem & privatus \\
\hline хі๊ & amicum & amicum & socium \\
\hline & benevolentiam & benevolentia & aritatem \\
\hline & suavitatem & suave & voluptatem \\
\hline & testudine & testudine & \\
\hline$\mu \omega ́ v \omega \nu$ & pratorum & prata & flores \\
\hline 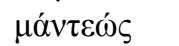 & vate & vatis & haruspice \\
\hline$\varepsilon \sigma \tau$ ¿̀ $\varsigma$ & plenus & plenus & outus \\
\hline & parva & parva & aca \\
\hline$\sigma \theta \tilde{\omega} \nu$ & mercede & mercede & retio \\
\hline$\sigma \varepsilon \rho \tilde{\omega} \nu$ & valetudinariis & valetudinariis & morbo \\
\hline 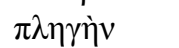 & verbera & verb & plagam \\
\hline$\lambda \eta \sigma \mu о v \tilde{\eta} \varsigma$ & repletione & repletionis & edacitate \\
\hline & fibula & fibula & spinter \\
\hline$\beta \alpha \tau o v$ & ovem & ovem & pecudem \\
\hline$\mu v o r s$ & catulis & catuli & fetus \\
\hline unvías & hara & hara & suillario \\
\hline uvovoíav & coitum & coitum & concupitum \\
\hline ótov & morem & morem & rationem \\
\hline & alimentorum & alimenti & cibi \\
\hline & contumeliam & contumeliam & iniuriam \\
\hline & sapores & sapores & humores \\
\hline & vituperiis & vituperationibus & ignominiae \\
\hline
\end{tabular}




\begin{tabular}{|c|c|c|c|}
\hline$\alpha i \rho \varepsilon \tilde{i} \sigma \theta \alpha \imath$ & eligere & eligenda & sequi \\
\hline$\dot{\alpha} v \theta i ́ \sigma \tau \alpha \tau \alpha \iota$ & resistit & resistunt & repugnat \\
\hline$\dot{\alpha} v i ́ \sigma \tau \alpha \tau \alpha \imath$ & exsurgit & surgens & consederit \\
\hline$\dot{\alpha} \pi \alpha \nu \tau \lambda \circ v ́ \mu \varepsilon v \alpha$ & hausti & hausti & manantia \\
\hline$\dot{\alpha} \pi \mathrm{o} \lambda \varepsilon i ́ \pi \varepsilon \mathrm{i}$ & deserit & deserit & omittit \\
\hline$\dot{\alpha} \sigma \pi \alpha ́ \zeta o \mu \alpha \imath$ & amplector & amplector & caritate prosequor \\
\hline$\delta 1 \varepsilon \xi \tilde{\eta} \lambda \theta \varepsilon \varsigma$ & disseres & disseruisti & persequebare \\
\hline$\delta เ \omega ́ \kappa \varepsilon เ v$ & persequi & persequi & quaerere \\
\hline$\delta \rho \varepsilon \pi о \mu \varepsilon ́ v \omega$ & decerpenti & decerpere & colligendo \\
\hline$\varepsilon \dot{\varepsilon} \alpha \pi \mathrm{o} \theta v \eta \dot{\sigma \kappa \kappa \varepsilon \iota}$ & moriuntur & immoriuntur & occidunt \\
\hline 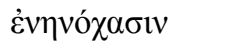 & evenit & invenitur & commiscuit \\
\hline 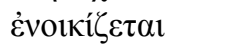 & inhabitat & habitat & inhaeret \\
\hline$\kappa \alpha \tau \alpha \beta 1 \alpha \zeta o ́ \mu \varepsilon v o \varsigma$ & vim inferens & vim afferre & opprimit \\
\hline$\kappa \alpha \tau \varepsilon 1 \rho \gamma \alpha ́ \sigma \alpha \nu \tau о$ & coercent & coercentur & efficiunt \\
\hline 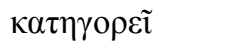 & accusat & accusat & reicit \\
\hline$\kappa о \sigma \mu о \tilde{\sigma} \sigma \alpha$ & ornans & exornat & moderatur \\
\hline$\kappa \rho \alpha \tau o v ́ \mu \varepsilon v \alpha$ & detentae & detenta & capta \\
\hline$\kappa v \vee \eta \gamma \varepsilon \tau \tilde{\omega} \nu$ & venans & venaretur & vestigans \\
\hline 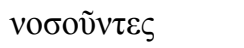 & aegrotantes & aegrotamus & morbo pertemptamur \\
\hline 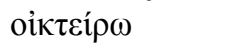 & miseremur & misereor & doleo \\
\hline$\pi \lambda \eta \sigma i \alpha ́ \zeta \varepsilon ı v$ & coire & coire & iungi \\
\hline$\pi \rho \circ \sigma \varepsilon ́ \varphi v \sigma \varepsilon$ & ingenuerit & ingenuit & armaverit \\
\hline$\sigma \kappa о \pi \varepsilon \tilde{v} v$ & excogitandi & excogites & adinvenias \\
\hline 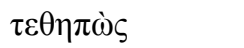 & stupidus & stupescebam & admirans \\
\hline$\tau \rho v \gamma \tilde{\omega} \nu \tau \imath$ & vindemianti & vindemiare & percipiendo \\
\hline 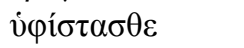 & subitis & subitis & suscipitis \\
\hline$\varphi \circ \beta о \tilde{v} v \tau \alpha \iota$ & timent & timent & formidant \\
\hline 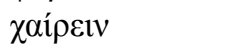 & valere & valere & non curat \\
\hline 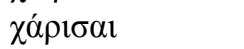 & largiaris & largire & tradis \\
\hline$\psi \varepsilon v ́ \delta \varepsilon \sigma \theta \alpha \iota$ & mentiri & mentiri & dissimulare \\
\hline$\dot{\alpha} \pi \lambda \tilde{\omega} \varsigma$ & simpliciter & simpliciter & temere \\
\hline$\gamma \grave{\alpha} \rho$ & enim & enim & quia \\
\hline 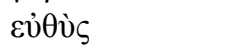 & statim & statim & haud multo post \\
\hline$\ddot{\varepsilon} \omega \varsigma$ & donec & donec & quamdiu \\
\hline$\mu \tilde{\alpha} \lambda \lambda \mathrm{ov}$ & immo & immo & potius \\
\hline$\mu \varepsilon ́ \chi \rho 1 \varsigma$ & donec & donec & quousque \\
\hline ő $\theta \varepsilon v$ & unde & unde & itaque \\
\hline ő $\lambda \omega \varsigma$ & omnino & omnino & nequaquam \\
\hline$\pi \alpha ́ v v$ & valde & valde & perquam \\
\hline$\pi \varepsilon \rho \alpha \imath \tau \varepsilon ́ \rho \omega$ & ulterius & ulterius & praeterea \\
\hline$\tau \alpha \chi v ́$ & cito & cito & facile \\
\hline$\omega ̋ \sigma \pi \varepsilon \rho$ & quemadmodum & quemadmodum & tamquam \\
\hline
\end{tabular}


Ami a mondatszerkesztést illeti, ahhoz nem férhet kétség, hogy Giovanni a szöveget saját magának újból összerakta, ezen a területen tehát várhatóan kevesebb befolyás mutatható ki. Egyrészt törekedett a fordítást is jobban a latin nyelv természetéhez igazítani, másrészt az eredeti kódexek is, amelyeket használt, több helyen eltérő olvasatot kínáltak. Nem utolsósorban pedig bizonyára az jelentette számára a valódi kihívást, hogy a saját önálló fordítását elkészítse.

Mindezek ellenére találni néhány olyan szöveghelyet, ahol a mondatszerkezetet hasonlóan véti el a két fordító, amiből könnyen támad az a benyomásunk, hogy valóban nem voltak függetlenek egymástól. Az egyik ilyen esetet Giovanni fordításában már tárgyaltuk. Ott felvetődött, hogy esetleg az iota subscriptum jelölésének a hiánya okozta a

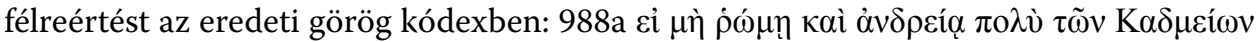
$\varepsilon \dot{\pi} \varepsilon \kappa \rho \alpha ́ \tau \varepsilon 1$. Giovanni fordítása úgy szólt: nisi virtus ac Thebanorum fortitudo domuisset, ám különös módon Birago is hasonlóan értelmezi a tagmondatot: nisi robur et fortitudo multum Thebanis praestitisset, vagyis a Sphinx nem tudott volna győzedelmeskedni, ha testi ereje és bátorsága nem múlta volna felül sokkal a thébaiakat.

Gryllos a Sphinx után további példákat említ a nőstény vadállatok bátorságára, így kerül szóba a teuméssosi róka és nem messze ezektől a kígyó, amely Apollónnal párharcot vívott a jósdáért Delphoiban. Az eredeti szövegben határozó szerepel az átveze-

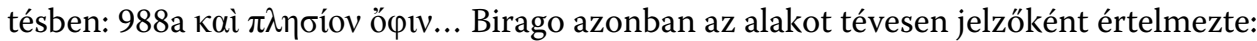
et proximam serpentem..., amit Giovanni kis módosítással megismétel: ac propinquam serpentem... Érdemes megemlíteni, hogy míg ez a félreértés Raffaele, sőt még Stephanus szövegében is kijavítatlanul maradt, addig Cassarino már a kezdetben is helyesen rakta össze a mondatot: et haud procul serpentem...

Az utolsó példában, amelyet idézünk, Gryllos a többi állat nevében is szemrehányást tesz Odysseusnak, hogy hiába nevezik őt a legokosabb embernek, ha egyszer megijedt a rosszabból a jobb állapotba való átalakulástól anélkül, hogy megvizsgálta

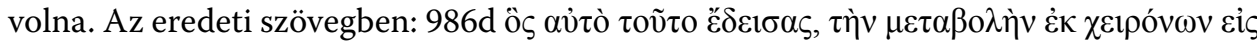

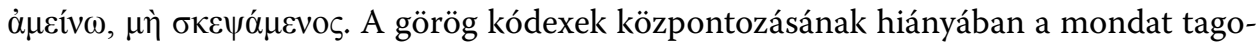
lása nehézségekbe ütközött. Minthogy a tárgyat újra felveszi a mondat, könnyen rendelhették a fordítók a második tárgyesetet a tagmondatot záró participiumhoz. Így járt el Birago: qui hoc ipsum timuisti, mutationem ex peioribus in meliorem inconsiderans, nemkülönben Giovanni, akinek a fordítása egyéb tekintetben is nagyon hasonló: tantum hoc ipsum timuisti, neque mutationem ex peioribus in meliora considerasti. Talán mondanunk sem kell, hogy ebben az esetben is Cassarino járt a helyes úton: qui transmutationem e deterioribus in melius pertimueris, nequaquam perspiciens.

Még ha Giovanni jó érzékkel és tudatosan átfogalmazta is Birago szövegét, sok helyen megragadható a fordításban az elődjéhez füződő szoros kapcsolat, különösen a jellemző szópárokban, többszavas felsorolásokban, sőt hosszabb-rövidebb tagmondatokban. Álljon itt ezekből néhány példa a szemléltetés kedvéért. A szópárokat és felsorolásokat ömlesztve adjuk meg: ex valetudinariis et stolidis Bir. ex valetudinariis ac stolidis GiReg.; amo... et amplector Bir. amo et amplector GiReg.; laudo... et admiror Bir. laudo et admiror GiReg.; laudare et probare Bir. laudanda probandaque GiReg.; eligere et amare Bir. eligenda atque amanda GiReg.; effert et auget Bir. effert 
atque auget GiReg.; laqueis aut dolis Bir. laqueis dolisve GiReg.; et voluptates et amores Bir. et voluptates et amores GiReg.; neque inordinate, neque insatiabiliter Bir. neque inordinate, neque insatiabiliter GiReg.; contumeliam et perturbationem confusionemque Bir. contumeliam et turbationem... atque confusionem GiReg.; a plantis et a seminibus Bir. a plantis atque seminibus GiReg.; inclinationes et choreas Bir. inclinationes et choreas GiReg.

Végül az egész tagmondatokra kiterjedő szerkezeti egyezések kétségen felül bizonyítják Giovanni szerves kapcsolatát Birago fordításával. A példákat itt is ömlesztve közöljük: si tibi esse calamitatem credam hominem ex fera fieri Bir. si tibi credidero calamitatem esse ex fera hominem fieri GiReg.; ac machinamentis homines simplicem generosumque belli morem Bir. ac machinationibus homines, qui simplicem ac generosum belli morem GiReg.; sed servientem consuetudinibus et vituperiis et opinionibus Bir. $\sim$ sed consuetudinibus ac vituperationibus ac vanis opinionibus servientes GiReg.; prudentia ferarum nulli inutilium artium vanarumque locum tribuit Bir. ferarum prudentia nulli inutilium vanarumque artium locum tribuat GiReg.; excogitandi ei nomen pulchrius et honoratissimum Bir. excogites ei pulchrius nomen atque honorificentius GiReg.

A Bruta animalia latin fordítása, amely a nyomtatott változatok révén nagyobb ismertségre tett szert a művelt olvasóközönség körében, több fázison keresztül jutott el végleges állapotába. Mint elemzésünk remélhetőleg megvilágította, Giovanni Regio fordítása képezte a középső láncszemet. A fiatal fordító kéziratban megőrződött szövege még a bátyja által ki nem javított változatában lehetővé teszi, hogy a fordítás többlépcsős folyamatának szálait mélyebben kibogozzuk. A szókészleti és mondatszerkesztési sajátosságok tüzetes vizsgálata feltárta, hogy Giovanni az eredeti szöveg feldolgozása során biztosan igénybe vette elődje, Lampugnino Birago fordítását, amelynek gyakorlati hasznát éppen rendkívüli szöveghűsége és tükörfordítás-jellege nyújtotta. A túlzottan pedáns fordítási stílusról azonban továbblépve egy pontos, de a latin nyelv követelményeinek jobban megfelelő fordítást készített. Ebben a fordításban azután bátyja, a komoly latin műveltséggel rendelkező Raffaele, akitől az ifjabb testvér görög-latin nyelvtudását és bizonyára stílusérzékét is tanulta, meglátta a lehetőséget, és húsz év múltán posztumusz kiadta. Magán a szövegen azonban gyökeres változtatásokat eszközölt. Így még az 1460-as években Birago műhelyéből kikerülő fordítás előbb Giovanni keze alatt esett át metamorfózison, amelynek során a szókészlet jelentős része átmentődött, azután pedig Raffaele szigorú tekintete alatt szenvedett el további változásokat, aki nemcsak mint lector, hanem mint corrector is közreműködött. A fél évszázadot átölelő javítási és átalakítási fázisok vezettek a Bruta animalia fordításának ma ismert változatához. 


\section{SUMMARY}

Plutarch's dialogue Bruta animalia ratione uti mainly reached popularity in humanist circles through a Latin translation made by Giovanni Regio, a young Paduan, in the year 1488. The text of this translation, which is preserved in a paper codex Ms. 958 of the University Library of Padua, was revised and posthumously put into print by Raffaele Regio, Giovanni's older brother, in the year 1508 in Venice. A comparison of the text of the manuscript with that of the printed version has so far been neglected in philological research. With a detailed analysis, we wish to ascertain how far changes have been effected to the original translation during the revision and try to get an insight into the methods and skills of the young translator. Thereby we shall even be able to trace if there is any further connection of the text with the other two translations of the dialogue, those that were made a few decades earlier by Antonio Cassarino and Lampugnino Birago.

Keywords: Plutarch, Bruta animalia ratione uti, Giovanni and Raffaele Regio, humanist Latin translations

Gaál Balázs

mithuna@t-online.hu 